\title{
When children are the least vulnerable to false memories: a true report or a case of autosuggestion?
}

Citation for published version (APA):

Brackmann, N., Otgaar, H., Sauerland, M., \& Jelicic, M. (2016). When children are the least vulnerable to false memories: a true report or a case of autosuggestion? Journal of Forensic Sciences, 61(S1), S271S275. https://doi.org/10.1111/1556-4029.12926

Document status and date:

Published: 01/01/2016

DOI:

10.1111/1556-4029.12926

Document Version:

Publisher's PDF, also known as Version of record

Document license:

Taverne

Please check the document version of this publication:

- A submitted manuscript is the version of the article upon submission and before peer-review. There can be important differences between the submitted version and the official published version of record.

People interested in the research are advised to contact the author for the final version of the publication, or visit the DOI to the publisher's website.

- The final author version and the galley proof are versions of the publication after peer review.

- The final published version features the final layout of the paper including the volume, issue and page numbers.

Link to publication

\footnotetext{
General rights rights.

- You may freely distribute the URL identifying the publication in the public portal. please follow below link for the End User Agreement:

www.umlib.nl/taverne-license

Take down policy

If you believe that this document breaches copyright please contact us at:

repository@maastrichtuniversity.nl

providing details and we will investigate your claim.
}

Copyright and moral rights for the publications made accessible in the public portal are retained by the authors and/or other copyright owners and it is a condition of accessing publications that users recognise and abide by the legal requirements associated with these

- Users may download and print one copy of any publication from the public portal for the purpose of private study or research.

- You may not further distribute the material or use it for any profit-making activity or commercial gain

If the publication is distributed under the terms of Article $25 \mathrm{fa}$ of the Dutch Copyright Act, indicated by the "Taverne" license above, 


\section{Efficient Processing of Sexual Assault Evidence Kits}

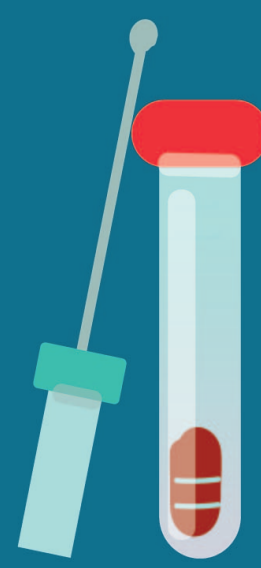

Choosing a SAEK processing workflow can be challenging for many forensic laboratories. While serology may be a familiar forensic technique, a "direct to DNA" approach using Y-screening can save time and money.

\section{Y-Screening > Serology}
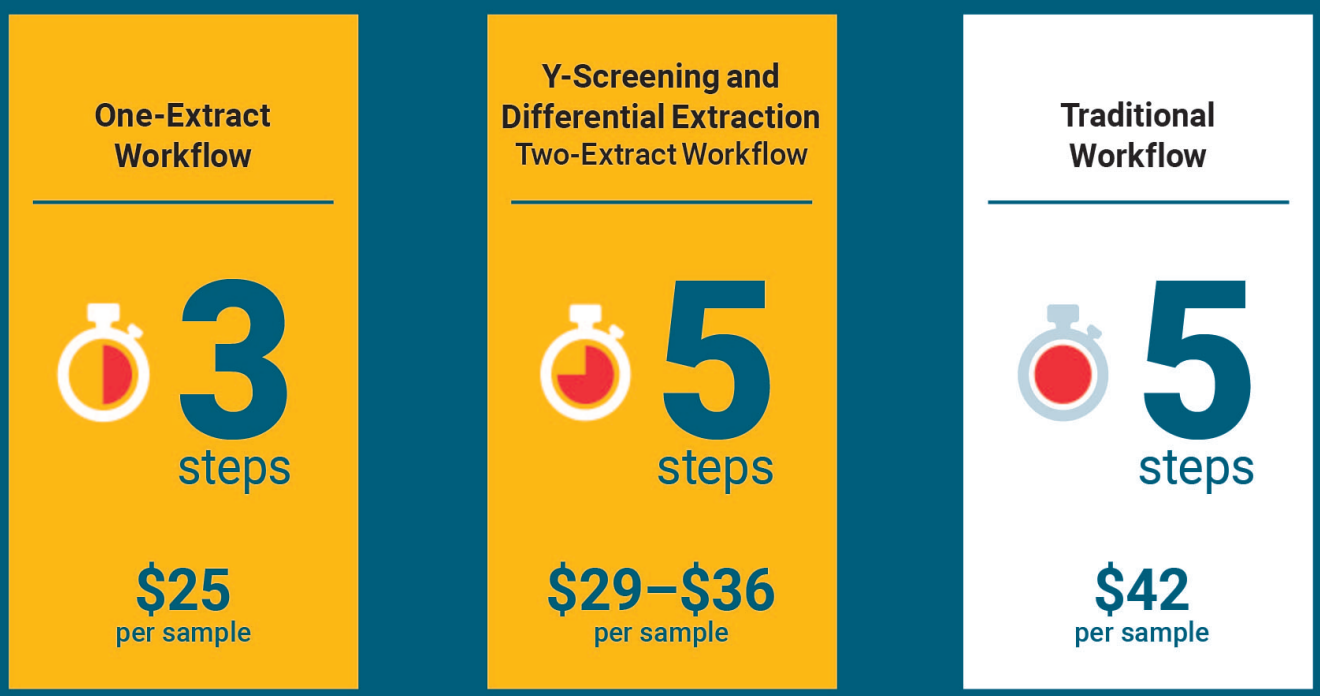

The Casework Direct System, when used with the PowerQuant ${ }^{\circledR}$ System, offers an ideal workflow to screen SAEK samples.

\section{Learn more at: www.promega.com/SAEK}




\title{
PSYCHIATRY \& BEHAVIORAL SCIENCE
}

\author{
Nathalie Brackmann, ${ }^{1,2}$ M.Sc.; Henry Otgaar, ${ }^{1,3}$ Ph.D.; Melanie Sauerland, ${ }^{1}$ Ph.D.; \\ and Marko Jelicic, ${ }^{1}$ Ph.D.
}

\section{When Children are the Least Vulnerable to False Memories: A True Report or a Case of Autosuggestion?}

\begin{abstract}
In this case report, a legal case revolving around the reliability of statements given by a 6-year-old girl is described. She claimed to have witnessed her mother being murdered by her father. Two psychological experts provided diametrically opposed opinions about the reliability of her statements. One expert, a clinician, opined that the girl's statements were based on autosuggestion whereas the other expert, a memory researcher, stated that autosuggestion was unlikely to have played a role. This case and the analysis of the experts' opinions illustrate what may happen when experts in court are unaware of the recent literature on (false) memory. That is, recent studies show that autosuggestion is less likely to occur in young children than in older children and adults. The current case stresses the importance and implications of relying on memory experts in cases concerning the reliability of eyewitness statements.
\end{abstract}

KEYWORDS: forensic science, eyewitness memory, children's testimony, expert witnesses, developmental reversal, false memory, memory

\section{Introduction}

Children are often involved in criminal trials in which they frequently act as witnesses and/or as victims of horrendous events (e.g., sexual abuse; 1,2). Their eyewitness accounts are frequently the only piece of evidence in such trials and, hence, much emphasis is placed on the reliability of their statements. The question of whether children's accounts are accurate or whether they have been infected with memory errors (e.g., false memories) due to suggestive influences is a central issue in these trials. This report outlines a recent case in which a memory phenomenon (i.e., developmental reversal) that has recently attracted much scientific attention played a pivotal role. Moreover, it demonstrates what may happen when expert witnesses are not acquainted with the intricacies of this memory phenomenon.

A considerable number of studies have been published on children's proneness to false memories. This research has revealed a consistent story, namely that young children are particularly more susceptible to conform to suggestive pressure than older children and adults (3). Specifically, it has been found that children are more likely to change their accounts and report false details than adults (i) when confronted with repeated questions on the same topic, (ii) when the questions imply the 'correct' answer, and (iii) when they are confronted with incorrect information (i.e., misinformation; 4).

${ }^{1}$ Section Forensic Psychology, Department of Clinical Psychological Science, Maastricht University, Maastricht, the Netherlands.

${ }^{2}$ Department of Psychology, University of Gothenburg, Sweden.

${ }^{3}$ Department of Psychology, City University, London, UK.

Received 15 July 2014; and in revised form 20 Jan. 2015; accepted 4 Feb. 2015.
Several paradigms have been introduced to study the production of false memories. In many of these paradigms, participants witness an event and are exposed to suggestive information. The basic question is whether participants fall prey to the damaging effects of suggestion on memory. One relevant paradigm is the implantation method in which participants receive false stories suggesting that they have ostensibly experienced a certain event (5). Participants are then asked to elaborate on these stories during multiple interviews. The principal result is that a significant minority $(30-40 \%)$ of participants remember the fictitious event and even endure in these false claims after debriefing (6).

Studies like these have also been executed with child participants. In one study, 7- and 11-year-olds were falsely told that they had received a rectal enema or that their finger had become stuck in a mousetrap when they were four years old across two interviews. Of most relevance to the current study was the finding that in the second interview, implanted false memories were more likely to be evoked in the 7-year-olds, compared to the 11-year-olds (7). Together, these studies provide important insights into the vulnerability of children to make false reports in legal settings, as they indicate that false reports of nonexperienced events might occur.

As an illustration of children's proneness to form false memories, it has been argued that in noteworthy child sexual abuse cases, such as the Kelly Michaels and the McMartin preschool cases, children fell prey to suggestive pressure. Specifically, parents, police or social workers likely influenced the children's reports as they apparently tried to confirm their prevailing opinion of the occurrence of sexual abuse while interviewing the children $(8,9)$. After long-lasting trials, the charges were dropped or the conviction was overturned, yet the ordeals entailed devastating consequences for the suspects' personal lives.

Based on the above-mentioned literature, one might be tempted to assume that children's memory reports are necessarily 
more likely to include false memories than those of adults. However, new findings indicate a contrary developmental pattern in which false memories increase with age (10). This phenomenon is called developmental reversal which refers to the finding that young children produce fewer false memories compared with older children and adults $(1,11)$. This effect has been replicated numerous times and a standard approach to study this developmental pattern is the Deese/RoedigerMcDermott (DRM) paradigm $(12,13)$. In the DRM paradigm, participants have to study lists with words that are associatively related to each other (e.g., dress, doll, cute, hair). One critical lure word (i.e., girl) is, however, missing from these lists. Despite the fact that participants do not encounter this word during the learning phase, a significant proportion still erroneously recollects it on subsequent memory tests. For example, a mean proportion of false recall of $10 \%$ in 5 -year-olds, compared to $44 \%$ in an adult sample was reported (14).

These false memories are caused by a reliance on the associative and semantic structure of the to-be-remembered material. That is, according to false memory theories, such as fuzzy-trace theory (FTT; 1$)$, when people experience events, two memory traces are stored as follows: verbatim traces and gist traces. Verbatim traces refer to memories of the item-specific surface details of an experience (e.g., the font of a word), while gist traces rely on the semantic background of presented material (e.g., that the words are related to "girl"). According to FTT, false memories are produced because people rely on gist traces when verbatim traces are not available during retrieval.

This reliance on the semantic structure is also emphasized by the associative-activation theory (AAT; 14,15) that postulates that spreading activation mechanisms determine the rate of false memories. Accordingly, during the encoding of events, information rapidly spreads to associated concepts in our knowledge often leading to the activation of related, but not presented concepts. This spreading activation then causes the formation of false memories.

It is important to emphasize that this type of false memory occurs without suggestive pressure and is spontaneously elicited. Intriguingly, recent studies have revealed that older children and adults are more likely to create these spontaneous false memories than young children (16). Reasons for this developmental pattern are that their knowledge base is less well developed and that they have more difficulties extracting the gist of experiences than older children and adults (15).

Interestingly, it has been demonstrated that developmental reversal effects are not only confined to word list research. Research has shown that developmental reversal effects emerge in forensically relevant paradigms as well. For example, false memories caused by co-witness effects were stronger in older children than in younger children (17). Furthermore, false memories that were induced by rumors increased with age (18). In summary, recent evidence shows that the assumption that false memories decrease with age is too simplistic and that, in certain situations, false memories might even increase with age. In the case that we describe here (see 19 for a Dutch overview) and in which one of the authors was involved as an expert witness (second author: $\mathrm{HO}$ ), we illustrate what may happen when psychologists are unaware of the nuances of these developmental false memory trends.

\section{The Vicky Case}

In this case, a six-year-old girl named "Vicky" (name has been changed to protect the child's identity) was regarded as the sole and chief witness of the murder of her mother. One night in May 2011, neighbors called the police because they had heard shouting and screaming next door. Upon their prompt arrival, Vicky opened the door and stated immediately: "My father was here. He just left. My father did it." When the police entered the house, they saw a woman lying on the floor in a pool of her own blood. The arriving ambulance personnel reported that she had been stabbed to death, and in their presence, Vicky repeated the allegation that her father had done it. Vicky was interviewed that same day in a child-friendly interview room in which she incriminated her father. Two months later, she was questioned once more and again, Vicky remained consistent: Her father was the perpetrator and killed her mother. According to Vicky, she was in her bedroom and heard noise on the main floor. She further declared that when she went downstairs, she saw her father stabbing her mother with a knife. The father denied all charges, and hence, Vicky proved to be a crucial witness in the trial against him.

\section{Autosuggestion?}

HO was asked by the public prosecutor to estimate the reliability of Vicky's accounts. His basic conclusion was that there were no strong reasons to doubt the statements of Vicky. The defense engaged another expert: a clinical psychologist (RB). This psychologist had a diametric opposite position. He argued that Vicky's statements were tainted by autosuggestion which is a subtype of spontaneous false memory. Both experts came to their evaluation by analyzing all case files and interview records. Specifically, they examined the circumstances of disclosure, the timeline, and content of statements, and the factors that might have tainted Vicky's memory. Based on the given information, they tested different scenarios possibly accounting for the statements. That is, they examined whether the file contained signs for a scenario in which the statements of Vicky were accurate but also assessed whether any elements were present for a scenario in which Vicky's statements were (partly) based on false memories. In the subsequent paragraphs, we address how the experts could reach such different conclusions.

The central argument of HO's report revolved around the spontaneity of Vicky's disclosure. Although in general children's memories work less optimal than adults', they are able to provide accurate statements (20). Indeed, although research indicates that negative experienced events can amplify false memory formation (21-24), there is an abundance of research indicating that negative and traumatic events are retained quite well in children's memory when no suggestive pressure is involved (25). Furthermore, case studies in which children's spontaneous statements were compared with objective evidence of the traumatic events (e.g., videos, photographs) have demonstrated that children's statements are accurate in the sense that their statements correspond to historical records, although omissions may occur $(26,27)$. In the Vicky case, it was unlikely that her statements were (suggestively) influenced before the first disclosure as her first statements to the police were offered spontaneously.

There were also other reasons in favor of the reliability of Vicky's statements. First of all, Vicky was interviewed on the same day in a child-friendly interview studio. There, she was questioned following a standardized non-suggestive free recall method with which even young children can give reliable and extensive reports (28). Research shows that early interviews can inoculate children's memory against subsequent suggestive information (29). Thus, the way in which Vicky was interviewed 
does not raise any concern about the reliability of her statements.

In addition, Vicky's statements were highly consistent across interviews. Although that does not imply that her statements were necessarily accurate (30), it does indicate that she did not change her statements continuously. Also, across interviews she provided extra information about what presumably had occurred; this increase in free recall output frequently occurs when children are interviewed in an appropriate manner (31).

$\mathrm{RB}$ predominantly based his line of reasoning and his conclusion on the idea of autosuggestion. This term was first introduced by Binet (1900) and refers to memory distortions that arise because of endogenous processes such as judgment and reasoning operations $(32,33)$. Autosuggestion has been regarded as a form of spontaneous false memory (1). According to RB, Vicky could not have seen the perpetrator because it was dark. Because of this circumstance, he concluded that it was very likely that she had made an incorrect association and developed a spontaneous false memory. RB argued that false memories due to autosuggestion are extremely likely to be developed in young children. Recent literature on this topic, however, paints a different picture. Spontaneous false memories and also autosuggestibility effects are least likely to be produced in younger children than in older children and adults (34). This effect is robustly found in different paradigms and forensically relevant circumstances. Brainerd and colleagues (16) give an overview of age increases in the aforementioned DRM paradigm and in Table 1 representative studies that used other paradigms are outlined. Moreover, it was noted by the police officers and reported by Vicky that the lamps near the crime scene were on, resulting in unimpaired illumination of the perpetrator.

Furthermore, RB argued that the mentioning of additional (i.e., reminiscent) details during Vicky's second interview was a strong sign of suggestive influences, and hence, probably false memories. Reporting more details in subsequent interviews, however, is not indicative of a false report. On the contrary, when a child is interviewed in a correct manner, they might feel more at ease to talk and familiar with the interview situation and therefore come up with more (accurate) information (38). Hence, the fact that Vicky's statements became more elaborate over time was not an indication of suggestive influences, but was more likely a consequence of appropriate interviewing methods. Furthermore, Vicky also remained consistent with the central aspect that her father was the perpetrator. After hearing both experts in court and mainly relying on Vicky's report, her father was found guilty and sentenced to 18 years in prison.

\section{Recommendations}

In general, expert witnesses who have to report on the reliability of eyewitness memory have no knowledge of the ground truth of a particular case (39). They can only provide evaluations on the likelihood of distorted memory based on scientific evidence that illustrates factors that might hamper memory. Each case is unique and should be analyzed with caution and with respect to the discrete circumstances of disclosure and interviewing. It is therefore vital that experts in court are aware of the state-of-the-art findings in, for example, the area of eyewitness memory and false memory (40).

New work in the field of false memory development shows the necessity to be constantly up to date regarding the literature on the functioning and development of memory (see also 41). As such, it illustrates that certain often-held assumptions about
TABLE 1-Age increases in false memory rates using forensically relevant paradigms.

\begin{tabular}{|c|c|c|}
\hline Paradigm & Age & Methodology and results \\
\hline $\begin{array}{l}\text { Eyewitness } \\
\text { identification }\end{array}$ & $5-12$ & $\begin{array}{l}\text { Subjects saw a video depicting a theft of a } \\
\text { wallet. In an identification task, only the } \\
11-/ 12 \text {-year-olds erroneously misidentified } \\
\text { a familiar innocent person that was also } \\
\text { present in the video as being the } \\
\text { perpetrator }(z=2.36 ; 35)\end{array}$ \\
\hline $\begin{array}{l}\text { Causal } \\
\text { narratives }\end{array}$ & $6,7,9,10,18$ & $\begin{array}{l}\text { Subjects saw photographs that depicted a } \\
\text { generally familiar scene. In a recognition } \\
\text { task, an age increase in inference errors } \\
\text { about the cause of a scene was } \\
\text { observed }\left(\eta_{p}^{2}=0.10 ; 36\right)\end{array}$ \\
\hline $\begin{array}{l}\text { Survival } \\
\text { processing }\end{array}$ & 8,11 & $\begin{array}{l}\text { Subjects had to rate the usefulness of } \\
\text { different words to survive in a hostile } \\
\text { environment or to move to a different } \\
\text { country, or to rate the pleasantness of } \\
\text { these words. In an unannounced free } \\
\text { recall test, older children were more } \\
\text { likely to report not presented words } \\
\text { than younger children }\left(\eta_{p}^{2}=0.14 ; 11\right)\end{array}$ \\
\hline $\begin{array}{l}\text { Emotional } \\
\text { memory }\end{array}$ & $7,11,20$ & $\begin{array}{l}\text { Subjects had to remember words of } \\
\text { different valence and arousal. Age } \\
\text { increases in recognition errors were } \\
\text { present in each valence/arousal } \\
\text { combination }\left(\eta^{2}=0.49\right) \text { but most } \\
\text { pronounced in high-arousal and negatively } \\
\text { valenced items }(21)\end{array}$ \\
\hline $\begin{array}{l}\text { Group } \\
\text { conformity }\end{array}$ & 6,11 & $\begin{array}{l}\text { Dyads saw slightly different videos of a gir } \\
\text { entering an office. Older children were } \\
\text { more likely to wrongfully incorporate } \\
\text { discussed but not seen elements in their } \\
\text { free recall report }\left(\eta^{2}=0.05 ; 17\right)\end{array}$ \\
\hline $\begin{array}{l}\text { Real-live } \\
\text { events }\end{array}$ & $5-12$ & $\begin{array}{l}\text { Subjects attended four birthday parties } \\
\text { with their friends. An age increase in } \\
\text { thematic source errors was present in the } \\
\text { subsequent interview indicating that older } \\
\text { children were more likely to misremember } \\
\text { an event having taken place at a specific } \\
\text { party than younger children (37) }\end{array}$ \\
\hline
\end{tabular}

Adjusted from (10). Studies have been selected to illustrate the phenomenon of developmental reversal in relation to the depicted case of "Vicky". These studies compare a sample comparable to Vicky's age (6 years old) with older participants.

the development of memory are incomplete and often flawed. This might result in the danger of under- or overestimating the likelihood of memory errors. Specifically, the default view that false memories are more likely to occur in children than in adults is outdated. As we have outlined, spontaneous false memories are less likely to occur in children than in adults. Even more, recent research on false memory formation shows that false memory development between children and adults is not fixed, but highly malleable. This work shows that depending on well-specified theoretical principles, false memories can decrease (when relying on verbatim information) or even increase (when relying on gist information) with age $(15,24)$.

The above-described case of the six-year-old witness Vicky emphasizes that experts need a profound contemporary knowledge of children's eyewitness memory when providing their expert opinion in court. This case shows what can happen when experts enter court and are still immersed with old and traditional ideas about child witnesses and memory in general. Such obsolete ideas might adversely affect jury decision-making and thus contaminate an entire case; eventuating in prolonged, costly trials, and potential misjudgments.

This view is shared by Zajac, Garry, Goodyear-Smith, and Hayne (2013) who pointed out that: "memory expert witnesses 
should provide evidence of their expertise" and "people whose primary occupation is clinical practice are not automatically qualified to give evidence on human memory" (42, p. 615). This view relates to recent research showing that many psychologists and psychiatrists who serve as expert witnesses do not significantly outperform general psychologists and psychiatrists on memory issues that may be discussed in court (43); ergo, these potential expert witnesses in court have sparsely and scanty knowledge of memory particularities. Such results emphasize that expert witnesses dealing with memory issues should demonstrate their familiarity with current research regarding memory that has been published in peer-reviewed journals.

A reasonable approach to tackle this issue is to define the qualification that is needed to give a balanced and contemporary evaluation of the reliability of witness statements and to communicate this to legal professionals. This process would ideally lead to a desirable situation where memory experts are more likely to serve as expert witnesses than solely practical working clinicians in cases concerning the reliability of statements. Thus, irrespective of occupational background (i.e., whether being a researcher or clinician), expert witnesses should be immersed in the up-to-date research literature concerning the case under investigation. This requirement of qualification is more likely to be fulfilled in an environment (such as a university) where a wide journal access is available and discussions about new findings of the particularities of memory are common. Additionally, guidelines defining the structure of an expert report should be developed. This could help to standardize evaluation methods and to facilitate comparisons between different experts. Another recommendation could be that memory experts are aided by the construction of a standardized "scoring" system consisting of memory findings in the literature known to harm and/or facilitate memory performance (e.g., suggestion, consistency). A case containing more elements that might have contaminated memory might lead to the conclusion to cast doubt on certain eyewitness statements. Implementing such new developments would be beneficial for the legal system. Indeed, if there is one area that truly benefits from findings obtained in science, it is the legal arena.

\section{Acknowledgments}

Supported by a fellowship from the Erasmus Mundus Joint Doctorate Programme in Legal Psychology (EMJD-LP; 20131438/001-001-EMII-EMJD) to Nathalie Brackmann and by a grant from the Edmund Hustinx Foundation and from the Netherlands Organization for Scientific Research (NWO 415-12003) to Henry Otgaar.

\section{References}

1. Brainerd CJ, Reyna VF, Ceci SJ. Developmental reversals in false memory: a review of data and theory. Psychol Bull 2008;134(3):343-82.

2. Howe ML. Memory lessons from the courtroom: reflections on being a memory expert on the witness stand. Memory 2012;21(5):576-83.

3. Bruck M, Ceci SJ. The suggestibility of children's memory. Annu Rev Psychol 1999;50(1):419-39.

4. Poole DA, Dickinson JJ, Brubacher SP. Sources of unreliable testimony from children. Roger Williams Univ Law Rev 2014;19(2):382-410.

5. Hyman IE Jr, Husband TH, Billings FJ. False memories of childhood experiences. Appl Cogn Psychol 1995;9(3):181-97.

6. Otgaar H, Scoboria A, Smeets T. Experimentally evoking nonbelieved memories for childhood events. J Exp Psychol Learn Mem Cogn 2013;39(3):717-30.
7. Otgaar H, Candel I, Scoboria A, Merckelbach H. Script knowledge enhances the development of children's false memories. Acta Psychol 2010;133(1):57-63.

8. Garven S, Wood JM, Malpass RS, Shaw JS III. More than suggestion: the effect of interviewing techniques from the McMartin Preschool case. J Appl Psychol 1998;83(3):347-59.

9. Schreiber N, Bellah LD, Martinez Y, McLaurin KA, Strok R, Garven S, et al. Suggestive interviewing in the McMartin Preschool and Kelly Michaels daycare abuse cases: a case study. Soc Influence 2006;1(1):16-47.

10. Brainerd CJ. Developmental reversals in false memory: a new look at the reliability of children's evidence. Curr Dir Psychol Sci 2013;22 (5):335-41.

11. Otgaar H, Smeets T. Adaptive memory: survival processing increases both true and false memory in adults and children. J Exp Psychol Learn Mem Cogn 2010;36(4):1010-6.

12. Deese J. On the prediction of occurrence of particular verbal intrusions in immediate recall. J Exp Psychol 1959;58(1):17-22.

13. Roediger HL, McDermott KB. Creating false memories: remembering words not presented in lists. J Exp Psychol Learn Mem Cogn 1995;21 (4):803-14.

14. Howe ML, Wimmer MC, Gagnon N, Plumpton S. An associative-activation theory of children's and adults' memory illusions. J Mem Lang 2009;60(2):229-51.

15. Otgaar H, Howe ML, Peters M, Smeets T, Moritz S. The production of spontaneous false memories across childhood. J Exp Child Psychol 2014;121:28-41.

16. Brainerd CJ, Reyna VF, Zember E. Theoretical and forensic implications of developmental studies of the DRM illusion. Mem Cognit 2011;39 (3):365-80.

17. Candel I, Memon A, Al-Harazi F. Peer discussion affects children's memory reports. Appl Cogn Psychol 2007;21(9):1191-9.

18. Principe GF, Guiliano S, Root C. Rumor mongering and remembering: how rumors originating in children's inferences can affect memory. J Exp Child Psychol 2008;99(2):135-55.

19. Otgaar H, Jelicic M, Merckelbach H. Het kind als getuige: enkele misvattingen [The child as witness: some misconceptions]. Expertise \& Recht 2014;1:20-6.

20. McWilliams K, Narr R, Goodman GS, Ruiz S, Mendoza M. Children's memory for their mother's murder: accuracy, suggestibility, and resistance to suggestion. Memory 2013;21(5):591-8.

21. Brainerd CJ, Holliday RE, Reyna VF, Yang Y, Toglia MP. Developmental reversals in false memory: effects of emotional valence and arousal. J Exp Child Psychol 2010;107(2):137-54.

22. Howe ML. Children's emotional false memories. Psychol Sci 2007;18 (10):856-60.

23. Howe ML, Candel I, Otgaar H, Malone C, Wimmer MC. Valence and the development of immediate and long-term false memory illusions. Memory 2010;18(1):58-75.

24. Otgaar H, Candel I, Merckelbach H. Children's false memories: easier to elicit for a negative than for a neutral event. Acta Psychol 2008;128 (2):350-4.

25. Goodman GS, Hirschman JE, Hepps D, Rudy L. Children's memory for stressful events. Merrill Palmer Q 1991;37(1):109-57.

26. Leander L, Christianson SA, Granhag PA. A sexual abuse case study: children's memories and reports. Psychiatr Psychol Law 2007;14(1):1209.

27. Orbach Y, Lamb ME. Assessing the accuracy of a child's account of sexual abuse: a case study. Child Abuse Negl 1999;23(1):91-8.

28. Lamb ME, Sternberg KJ, Orbach Y, Esplin PW, Stewart H, Mitchell S. Age differences in young children's responses to open-ended invitations in the course of forensic interviews. J Consult Clin Psychol 2003;71 (5):926-34.

29. Quas JA, Malloy LC, Melinder A, Goodman GS, D’Mello M, Schaaf J. Developmental differences in the effects of repeated interviews and interviewer bias on young children's event memory and false reports. Dev Psychol 2007;43(4):823-37.

30. Smeets T, Candel I, Merckelbach H. Accuracy, completeness, and consistency of emotional memories. Am J Psychol 2004;117(4):595-609.

31. Goodman GS, Quas JA. Repeated interviews and children's memory: it's more than just how many. Curr Dir Psychol Sci 2008;17(6):386-90.

32. Binet A. La suggestibilité. Paris, France: Schleicher Freres, 1900;391.

33. Brainerd CJ, Reyna VF. Autosuggestibility in memory development. Cogn Psychol 1995;28(1):65-101.

34. Principe GF, Schindewolf E. Natural conversations as a source of false memories in children: implications for the testimony of young witnesses. Dev Rev 2012;32(3):205-23. 
35. Ross DF, Marsil DF, Benton TR, Hoffman R, Warren AR, Lindsay RC, et al. Children's susceptibility to misidentifying a familiar bystander from a lineup: when younger is better. Law Hum Behav 2006;30(3):249-57.

36. Lyons KE, Ghetti S, Cornoldi C. Age differences in the contribution of recollection and familiarity to false-memory formation: a new paradigm to examine developmental reversals. Dev Sci 2010;13(2):355-62.

37. Odegard TN, Cooper CM, Lampinen JM, Reyna VF, Brainerd CJ. Children's eyewitness memory for multiple real-life events. Child Dev 2009;80(6):1877-90.

38. Azad A, Christianson S-Å, Selenius H. Children's reporting patterns after witnessing homicidal violence - the effect of repeated experience and repeated interviews. Psychol Crime Law 2013;20(5):407-29.

39. Bidrose S, Goodman GS. Testimony and evidence: a scientific case study of memory for child sexual abuse. Appl Cogn Psychol 2000;14(3):197213.

40. Chin JM. Psychological science's replicability crisis and what it means for science in the courtroom. Psychol Public Policy Law 2014;20(3):1-14.

41. Goodman GS, Goldfarb DA, Chon JY, Goodman-Shaver L. Sources of unreliable testimony from children. Roger Williams Univ Law Rev 2014;19(2):476-512.
42. Zajac R, Garry M, London K, Goodyear-Smith F, Hayne H. Misconceptions about childhood sexual abuse and child witnesses: implications for psychological experts in the courtroom. Memory 2013;21(5):608-17.

43. Melinder A, Magnussen S. Psychologists and psychiatrists serving as expert witnesses in court: what do they know about eyewitness memory? Psychol Crime Law 2015;21(1):1-9.

Additional information and reprint requests:

Nathalie Brackmann, M.Sc.

Section Forensic Psychology

Department of Clinical Psychological Science

Faculty of Psychology and Neuroscience

Maastricht University

Maastricht

The Netherlands

E-mail: n.brackmann@maastrichtuniversity.nl 